\title{
Multi-Integrated Systems for Treatment of Abattoir Wastewater: A Review
}

\author{
Larryngeai Gutu $^{1}$, Moses Basitere ${ }^{2, *}$, Theo Harding ${ }^{3}$, David Ikumi ${ }^{3} \mathbb{D}$, Mahomet Njoya $^{1} \mathbb{D}$ and Chris Gaszynski ${ }^{3}$ \\ 1 Department of Chemical Engineering, Bioresource Engineering Research Group (BioERG), \\ Cape Peninsula University of Technology, P.O. Box 1906, Bellville 7535, South Africa; \\ 216000157@mycput.ac.za (L.G.); mahomet.njoya@gmail.com (M.N.) \\ 2 Academic Support Programme for Engineering in Cape Town (ASPECT) \& Water Research Group, \\ University of Cape Town, Rondebosch, Cape Town 7700, South Africa \\ 3 Department of Civil Engineering, Water Research Group, University of Cape Town, Rondebosch, \\ Cape Town 7700, South Africa; theo.harding@uct.ac.za (T.H.); david.ikumi@uct.ac.za (D.I.); \\ chris.gaszynski@uct.ac.za (C.G.) \\ * Correspondence: moses.basitere@uct.ac.za
}

Citation: Gutu, L.; Basitere, M.; Harding, T.; Ikumi, D.; Njoya, M.; Gaszynski, C. Multi-Integrated Systems for Treatment of Abattoir Wastewater: A Review. Water 2021 13, 2462. https://doi.org/10.3390/ w13182462

Academic Editors: Amin Mojiri and Mohammed J.K. Bashir

Received: 21 July 2021

Accepted: 30 August 2021

Published: 7 September 2021

Publisher's Note: MDPI stays neutra with regard to jurisdictional claims in published maps and institutional affiliations.

Copyright: (C) 2021 by the authors. Licensee MDPI, Basel, Switzerland. This article is an open access article distributed under the terms and conditions of the Creative Commons Attribution (CC BY) license (https:// creativecommons.org/licenses/by/ $4.0 /)$
Abstract: Biological wastewater treatment processes such as activated sludge and anaerobic digestion remain the most favorable when compared to processes such as chemical precipitation and ion exchange due to their cost-effectiveness, eco-friendliness, ease of operation, and low maintenance. Since Abattoir Wastewater (AWW) is characterized as having high organic content, anaerobic digestion is slow and inadequate for complete removal of all nutrients and organic matter when required to produce a high-quality effluent that satisfies discharge standards. Multi-integrated systems can be designed in which additional stages are added before the anaerobic digester (pre-treatment), as well as after the digester (post-treatment) for nutrient recovery and pathogen removal. This can aid the water treatment plant effluent to meet the discharge regulations imposed by the legislator and allow the possibility for reuse on-site. This review aims to provide information on the principles of anaerobic digestion, aeration pre-treatment technology using enzymes and a hybrid membrane bioreactor, describing their various roles in AWW treatment. Simultaneous nitrification and denitrification are essential to add after anaerobic digestion for nutrient recovery utilizing a single step process. Nutrient recovery has become more favorable than nutrient removal in wastewater treatment because it consumes less energy, making the process cost-effective. In addition, recovered nutrients can be used to make nutrient-based fertilizers, reducing the effects of eutrophication and land degradation. The downflow expanded granular bed reactor is also compared to other high-rate anaerobic reactors, such as the up-flow anaerobic sludge blanket (UASB) and the expanded granular sludge bed reactor (EGSB).

Keywords: bio-membrane; multi-integrated system; expanded granular bed reactor; anaerobic digestion; activated sludge; membrane bioreactor

\section{Introduction}

The continuous influx and increase in urbanization and industrialization have led to an increase in the consumption of goods and services. Relative to other commodities such as winery and car manufacturing, the abattoir industries have also increased and doubled in production in the past decade, increasing water consumption. This increase in water consumption inevitably poses a threat to the environment due to added pollution and increasing water scarcity such that by 2050 global water demand is projected to be 20-30\% higher than current levels given both population growth and socio-economic development [1].This is caused by the presence of organic matter such as chemical oxygen demand (COD), which poses a threat to the environment by accelerating the deoxygenation of rivers and contamination of ground water [2]. Abattoir industries consume about 
$26 \mathrm{~L}$ of potable water per bird to clean the blood off of slaughtered animals, clean off the slaughtering surfaces, cleaning of by-products, steam generation, and for chilling [3]. The slaughtering process and the periodic washing of residue particles in the slaughterhouse result in large quantities of water containing high amounts of biodegradable organic matter $[4,5]$. The contribution of organic load to these effluents usually comes from different materials such as undigested food, blood, fats, oil, and grease (FOG) and lard, loose meat, paunch, colloidal particles, soluble proteins, manure, grit, and suspended materials [4]. Farzadkia, Vanani [6] stated that the characterization of abattoir wastewater contaminants is influenced by the type of treated water, the kind of animals that have been slaughtered for the particular time frame leading up to water collection, the sampling techniques of the individuals involved, as well as the cleaning and sanitizing procedures of a specific abattoir. These wastewater contaminants can be further characterized into three categories, as shown in Figure 1. Biological oxygen demand (BOD), chemical oxygen demand (COD), and total organic carbon (TOC) are the most widely used parameters for testing effluent quality before discharge according to discharge standards, as shown in Table 1.

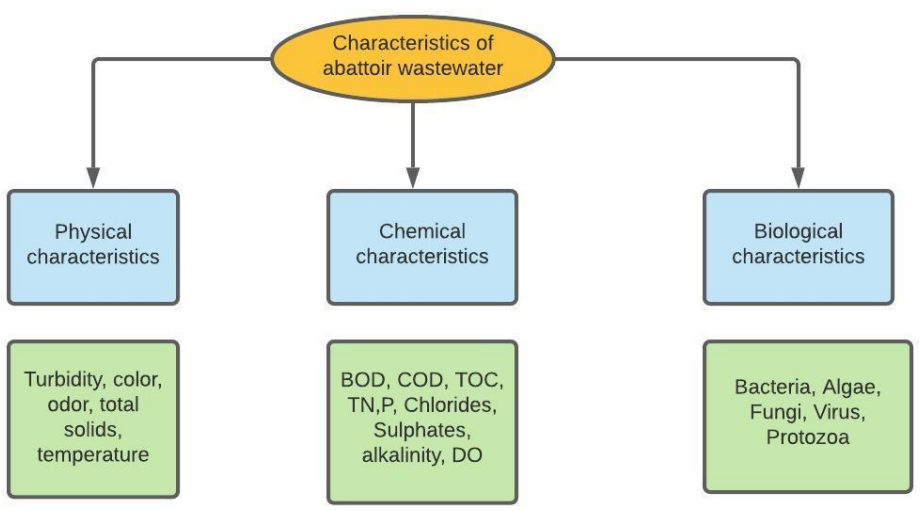

Figure 1. Characteristics of abattoir wastewater [Abbreviations: BOD biological oxygen demand; COD chemical oxygen demand; TOC total organic carbon; TN total nitrogen, P phosphorus; DO dissolved oxygen] [7].

Table 1. Maximum limits permitted by the City of Cape Town: Wastewater and Industrial Effluent By-law 2013 and the characteristics of different abattoir wastewater.

\begin{tabular}{|c|c|c|c|c|c|c|}
\hline & & $\begin{array}{c}\text { CCT Industrial } \\
\text { Effluent by-Law (2013) }\end{array}$ & $\begin{array}{c}\text { SANS 214:2011 } \\
\text { (Portable Water Quality) }\end{array}$ & $\begin{array}{c}\text { AWW } \\
{[8]}\end{array}$ & $\begin{array}{c}\text { AWW } \\
\text { [9] }\end{array}$ & $\begin{array}{c}\text { AWW } \\
{[10]}\end{array}$ \\
\hline Parameter & Unit & Maxim & am limits & Range & Range & Range \\
\hline \multicolumn{7}{|c|}{ General limits } \\
\hline Temperature & ${ }^{\circ} \mathrm{C}$ & 40 & - & - & - & - \\
\hline Conductivity at $25^{\circ} \mathrm{C}$ & $\mathrm{mS} / \mathrm{m}$ & 500 & 170 & - & - & - \\
\hline $\mathrm{pH}$ at $25^{\circ} \mathrm{C}$ & $\mathrm{n} / \mathrm{a}$ & 12 & 9.7 & $6.5-8.0$ & $5-7.8$ & 6.5 \\
\hline Chemical oxygen demand (COD) & $\mathrm{Mg} / \mathrm{L}$ & 5000 & - & $\begin{array}{l}2133- \\
10,655\end{array}$ & $\begin{array}{r}1100- \\
15,000\end{array}$ & 8575 \\
\hline Turbidity & NTU & - & $1 / 5$ & - & - & - \\
\hline \multicolumn{7}{|c|}{ Chemical substance limits } \\
\hline Total dissolved solids (TDS) & $\mathrm{mg} / \mathrm{L}$ & 4000 & 1200 & - & & - \\
\hline Total suspended solids (TSS) & $\mathrm{mg} / \mathrm{L}$ & 1000 & - & $315-1273$ & $220-6400$ & 1550 \\
\hline Fats, oils and greases (FOGs) & $\mathrm{mg} / \mathrm{L}$ & 400 & - & $131-684$ & $40-1385$ & 121.5 \\
\hline Ammonium as (N) & $\mathrm{mg} / \mathrm{L}$ & - & 1.5 & $29-51$ & $20-300$ & - \\
\hline Nitrates as (N) & $\mathrm{mg} / \mathrm{L}$ & - & 11 & - & $50-840$ & 455 \\
\hline Nitrites as (N) & $\mathrm{mg} / \mathrm{L}$ & - & 0.9 & - & $40-700$ & 455 \\
\hline Total phosphates as (P) & $\mathrm{mg} / \mathrm{L}$ & 25 & - & $8-30$ & $15-200$ & 112.5 \\
\hline
\end{tabular}


The discharge of untreated water not only poses a severe threat to public health but also causes the death of aquatic species and eutrophication, leading to the depletion of dissolved oxygen (DO) and possible emanation of harmful gases [9,11]. Blood and fat are a major problem in contaminated AWW. Blood has a COD of $375000 \mathrm{mg} / \mathrm{L}$ which is considered very high and on the other hand, fats cause physical problems in treatment plants such as blockages, clogging, scum formation and possible shut downs [2]. Governments have imposed strict regulations on the discharge of water to mitigate the expenses of pollution, for which non-compliance results in heavy penalties. Each municipality in South Africa has regulation standards for water discharge, whether it is into the sewers, land applications or for onsite reuse.

Due to the high costs associated with the efforts to reduce and handle waste, abattoirs are aiming to treat the wastewater onsite with the possibility of reusing and recycling to reduce plant running costs, have a smaller footprint, as well as upgrading to newer cost-effective technologies. The increase in onsite treatment and waste eradication requires advanced refuse-handling equipment and methods to produce organic-rich and less biotoxic waste [12]. The wastewater can be treated using biological and chemical treatment. Recently, chemical treatment has become less popular as the use of chemicals increases the cost of treatment, leaves the difficult task of disposing of the chemical sludge and is environmentally unfriendly, making this option uneconomical and unfavorable [9]. As a result, aerobic and anaerobic treatment systems have become dominant and favorable options $[9,13]$. AWW contains high concentrations of organic contaminants and is rich in proteins and lipids, making it ideal for biogas production [4], as well as being a good candidate for the highly attractive anaerobic digestion [5]. According to Ozdemir and Yetilmezsoy [14], analysis confirmed that the bio-diesel produced from the waste fats, oils and grease (FOG) obtained from slaughterhouse waste showed excellent fuel properties when compared to biodiesel produced from other common crop-based feedstocks. This is because AWW is protein and lipid rich and has great potential to produce high methane yields at different concentrations of volatile solids.

Anaerobic treatment is advantageous as it has excellent eco-friendly organic matter removal, less sludge production, lower energy consumption, execution of higher organic loading rates (OLR), fewer nutrients and chemical requirements, high COD and BOD removal efficiency, and requires a smaller footprint as well as the considerable production of renewable energy in the form of biogas $[15,16]$. However, anaerobic digestion poses some limitations, such as having longer start-up and running periods, sensitivity to higher temperature conditions and the inability to effectively remove nutrients such as nitrogen and phosphates, which results in low to moderate effluent quality [17]. Additionally, the process often faces operational challenges due to the difficulties related to the treatment of suspended solids, fats, oils and grease (FOGs) accumulating in the reactors, leading to reduced methanogenic activity, as well as sludge and biomass washout $[4,18,19]$. These challenges result in process failure, hence the need to incorporate pre-treatment for FOG removal, initiate hydrolysis, and remove solid particles and feathers.

Mondal, Jana [20] stated that aerobic treatment is superior to anaerobic treatment for treating water with a high organic content because it is quicker and more effective for degrading contaminants. However, aerobic digestion also has its flaws, such as high energy requirements for aeration compared to anaerobic, which adds to running costs. Hence a combination of both anaerobic and aerobic processes must be employed to tackle this predicament and effectively remove the nutrients and organic matter [4,9]. The fraction of lipids presents in AWW poses a threat due to their slow hydrolysis rate [21]. Typically, induced and dissolved air flotation is used to remove the oils and grease before aerobicanaerobic digestion. However, the costs of the air and reagents used, if chemically assisted, tend to make this process uneconomical and expensive. Additionally, the removal efficiency is low and sometimes produces difficult sludges to treat [15]. Other methods tested include alkaline, thermal [22,23] and ultrasonic [24] pre-treatment; however, these all fall short in one way or another. Enzymatic pre-treatment is a good option to satisfy the concerns of 
improving methane production, reducing the number of suspended solids before anaerobic digestion and is environmentally friendly [19]. Enzymes hydrolyse the triglycerides to fatty acids and glycerol, which improves the efficiency of biodegradation by microorganisms and eases operation during biological treatment [15]. A study done by Zhang, Zou [19] compared the stability of anaerobic digestion by feeding enzyme pre-treated water vs non-pre-treated water. The reactor containing the enzyme pre-treated feed showed higher stability during operation, even at higher organic loading rates (OLR).

Although it may be a great option, it is not economically feasible to use commercial enzymes practically in engineering practice, as most enzymes have to be significantly monitored as they are sensitive to temperature and $\mathrm{pH}$, and some cannot digest all the organic matter present [19]. An economic and feasibility study done by [15], without considering the ability of methane production to offset costs, revealed that using enzymes to pre-treat wastewater with high fat content has lower installation and operational costs than the traditional technologies. Therefore, it is still a better and cheaper alternative with great potential, despite its complex operation if methane generation is considered as an income generating byproduct. Alternatively, the application of biosurfactants produced by micro-organisms has recently been reported in studies as a cheaper alternative to commercial enzymes [25]. The biosurfactants enhance biodegradation by dissolving FOGs and can be incorporated simultaneously into the biological aeration process, reducing the number of stages for pre-treatment. Other advantages include lower capital and operation costs, reduction in operational problems, as well as an increase in methane production through anaerobic digestion $[15,26]$.

This review highlights the importance of using biological processes in wastewater treatment. The use of a bioremediation agent known as the eco-flush, a product developed by Mavu Biotechnologies (Pty) limited during aerobic treatment, is a novel method that has not been extensively researched. Still, it can pose as an economical and more preferable approach when compared to pure commercial enzymes. Since biological processes are generally slow and not adequate, a multi-integrated system approach can be used, where each stage focuses solely on removing a particular nutrient or pathogen.

\section{Analytical Methods for Testing Water Quality}

Measurements need to be performed to check if the treated water complies with municipal discharge regulations. The analytical methods are all outlined in the Environmental protection agency (EPA) handbook, and each analysis is specifically coded. Analysis can be tested on: $\mathrm{pH}$ (EPA 9040C), temperature, total dissolved solids (TDS) (EPA 160.1), salinity (EPA 320), turbidity (EPA 180.1), total suspended solids (TSS) (EPA 160.2), volatile suspended solids (VSS) (EPA 1684), COD (EPA 410.4), ammonium (EPA 350.1), nitrates concentration (EPA 353.4), biological oxygen demand (BOD) (EPA 405.1), volatile fatty acids (VFAs) (EPA 8260D) and fats, oils and grease (FOGs) (EPA 1664A). Monitoring the efficiency of a wastewater treatment plant is essential. One of the widely used methods for presenting water quality data is the water quality index (WQI) approach. A summary of different water quality parameters is calculated to a single number, which helps define the general quality status of water and its suitability for various purposes like drinking, irrigation, fishing etc., [27].

\section{Aerobic Treatment}

Aerobic treatments involve the treatment of sludge with air in the presence of aerobic or facultative anaerobic microbes before anaerobic digestion [9]. Oxygen is injected into the treatment system, which accelerates the hydrolysis rate of the organics by enhancing the activity of the micro-organisms [28]. Aerobic treatment prior to anaerobic digestion improves the hydrolysis stage, the sludge solubilization, accelerates hydrolytic activities, increases the methane yield by $20-50 \%$, and decreases VS by $21-64 \%$ [28]. This suggests that aerobic pre-treatment does not decrease the methanogenic activity of methanogens within the anaerobic digester and can be a great addition to a multi-stage system [28]. Besides 
being used in the pre-treatment stages, aerobic processes can be employed after anaerobic digestion to enhance nutrient removal. The required oxygen and treatment time correlate with the strength of the AWW being treated [29]. Due to the expenses incurred during the pumping of artificial oxygen and maintenance, using aerobic treatment for extended periods becomes uneconomical and produces large volumes of biomass. Furthermore, due to the benefits of aerobic treatment, it can be incorporated for shorter processes such as before anaerobic digestion and for nutrient removal after the digester. This will ensure maximum organic matter removal and lower costs, as the processes are relatively short. Despite the higher running costs compared to anaerobic digestion, aerobic treatment has some advantages, such as low odor production and a fast-biological growth rate [30].

\section{Aeration Pretreatment Using Enzymes}

Enzymes are used to accelerate the hydrolysis of macromolecules to enhance anaerobic digestion [21]. Pre-treatment is included to ensure complete degradation during anaerobic digestion at shorter hydraulic retention times (HRT). Enzymes breakdown the bonds between the triglycerides and hydrolyze them to basic components of fatty acids and glycerol, thereby giving the aerobic micro-organisms a higher chance to biodegrade the FOGs [15]. An eco-flush is an Ergofito's commercially manufactured bioremediation agent supplied in South Africa by Mavu Biotechnologies. An eco-flush is a mixture of natural ingredients and bacteria with the ability to remain dormant until a rich organic source, which acts as a substrate (such as AWW), is applied to activate them, primarily producing enzymes for hydrolysing FOGs [31,32]. Its natural ingredients are derived from glaucids and essential amino acids, which form powerful decomposing agents that stimulate the natural predisposition of certain bacteria to produce enzymes. These enzymes are capable of breaking down the hydrocarbon chains in FOGs and also compete with the bacteria that are responsible for producing Ammonia $\left(\mathrm{NH}_{3}\right)$ and Hydrogen Sulphide $\left(\mathrm{H}_{2} \mathrm{~S}\right)$, which results in no to less odor during pre-treatment [31]. The eco-flush can be added to raw AWW at the desired ratio as shown in Figure 2, a systematic diagram representing the pretreatment stage before anaerobic digestion. Artificial aeration is required to facilitate the bacteria to produce enzymes to degrade the FOGs by providing oxygen as an electron acceptor. For successful enzymatic pre-treatment, several parameters such as temperature, $\mathrm{pH}$, substrate quantity and enzymes stability have to be assessed and optimized [28].

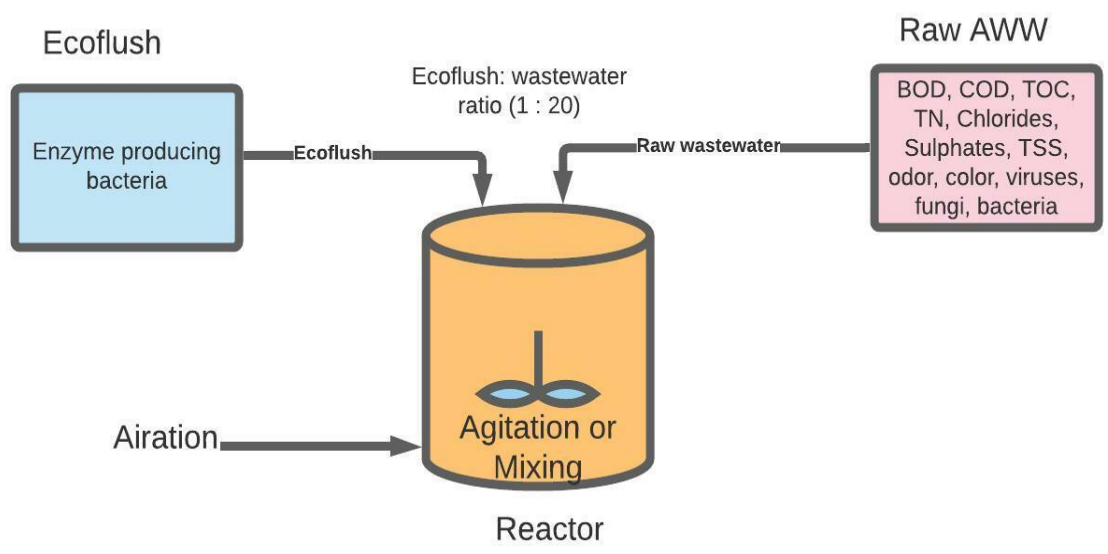

Figure 2. AWW pre-treatment stage using an eco-flush.

Generally, the oxidation of $1 \mathrm{~kg}$ of COD requires $1 \mathrm{kWh}$ of aeration energy when the aerobic treatment is selected for wastewater treatment [33]. Oxygen is slightly soluble in water and has to be transferred from the gas phase to the liquid phase, which is called absorption, driven by the concentration gradient between the atmosphere and the bulk liquid $[33,34]$. The aeration requirement results in the need for a large surface for efficient oxidation of the organic matter, which increases the running costs [33]. 
Although an aerated pre-treatment stage improves the anaerobic digestion as mentioned previously, the presence of dissolved oxygen in the treated wastewater can also inhibit the methanogenic activity in the anaerobic digestion stage. One critical parameter for a good performance of anaerobic treatment is the lack of oxygen. This is usually determined through the redox potential that should remain $<-50 \mathrm{mV}$ for anaerobic digestion and $<-300 \mathrm{mV}$ for a good methanogenic activity [35]. For a hermetically closed digester, there is usually no need to attempt to remove the oxygen present, as the BOD in the wastewater consumes the oxygen present rapidly since aerobes and facultative aerobes normally use $100 \mathrm{mg} / \mathrm{L}$ of dissolved oxygen to degrade $100 \mathrm{mg} / \mathrm{L}$ of BOD [33]. Furthermore, for lab studies and industrial scales, oxygen removal must be implemented through nitrogen purging, which includes three main methods [35], namely: Displacement purging, Pressurizing purging, and Dilution purging. Purging consists of the replacement of one gas by another in an enclosed chamber or space, e.g., removal of oxygen and replacing it with nitrogen gas in anaerobic digestion [34]. Therefore, before the pre-treated water is fed into the anaerobic digester, the Dissolved Oxygen must be monitored.

A study done by [36] a pre-treatment using an Ecoflush bioremediation agent was implemented and resulted in FOG removal of $80 \%$ and the TSS and COD removal which reached $38 \%$ and $56 \%$, respectively, before feeding the slaughter wastewater into the anaerobic digester. Meyo, Njoya [32] also did a similar study on the pre-treatment of Poultry Slaughter Wastewater (PSW), and the removal percentages varied between 20 and $50 \%$ for total suspended solids (TSS), 20 and 70\% for chemical oxygen demand (COD), and 50 and $83 \%$ for fats, oil, and grease (FOG) before anaerobic treatment using an EGSB reactor. These studies are among the few that reported the use of an Ecoflush reagent. The removal efficiencies do suggest there is potential in bioremediation technology as a pre-treatment stage for high fat content wastewater.

\section{Anaerobic Digestion}

Anaerobic digestion is a degradation process that occurs in the absence of oxygen to produce methane and carbon dioxide. It consists of four stages: hydrolysis, acidogenesis, acetogenesis, and methanogenesis, as shown in Figure 3. The hydrolysis stage reduces insoluble organic matter and high molecular weight compounds such as polysaccharides, proteins, and lipids into monosaccharides and amino and fatty acids [37]. During acidogenesis, acidogenic bacteria produce volatile fatty acids, carbon dioxide, hydrogen sulphide, ammonia and other by-products, using the components formed during hydrolysis [29]. Acetogenesis is the third stage in which acetic acid, carbon dioxide and hydrogen are produced from the digestion of higher alcohols and organic acids. Methanogenesis is the last and final step in which methane gas is produced by methanogenic bacteria [37]. The production and accumulation of volatile fatty acids (VFAs) can cause a drop in $\mathrm{pH}$, which can affect methane production. Consequently, the VFA: alkalinity ratio is a critical factor in determining reactor performance and should in no case exceed $0.3[9,38]$. Besides a $\mathrm{pH}$ range of 6.8-7.2, the organic matter loading/substrate ratio largely affects biogas production, where either too little or too much can cause a slow digestion process and should in no case be $>0.3$ [9]. 


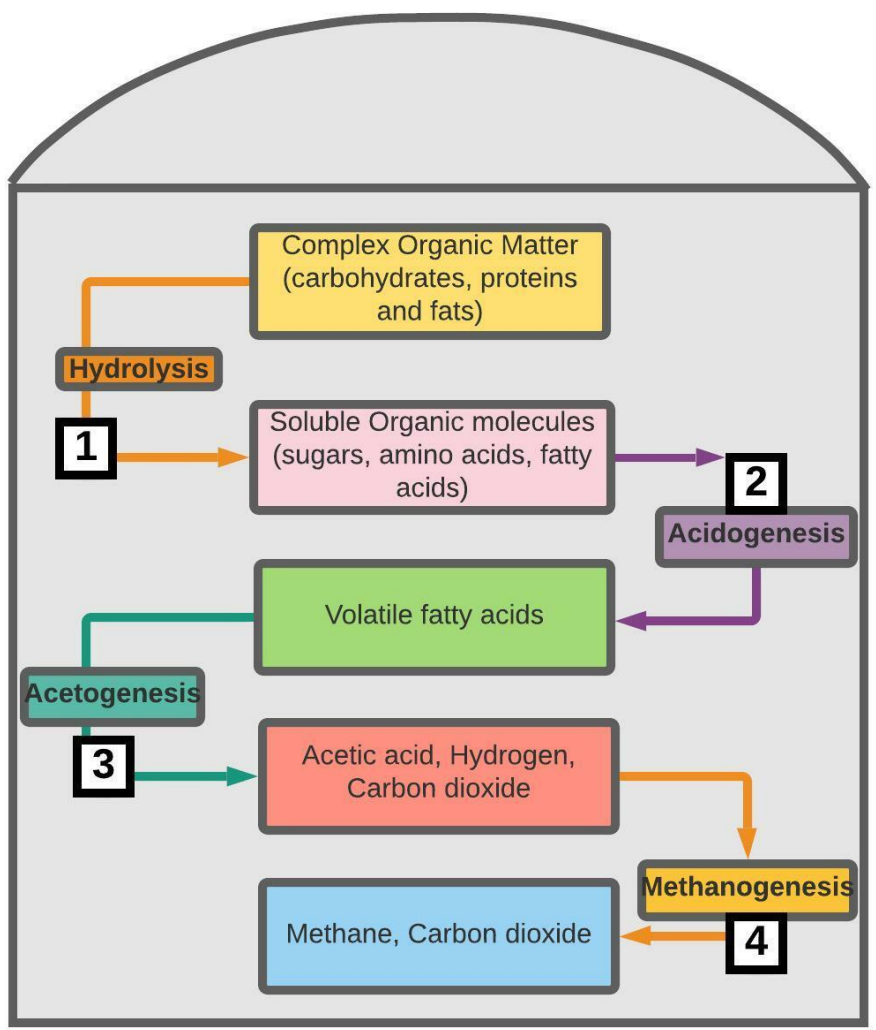

Figure 3. Anaerobic digestion stages in an anaerobic reactor.

\section{High-Rate Anaerobic Reactors (HRABS)}

High-rate anaerobic digesters have been a subject of increasing interest, due to their high loading capacity and low sludge production. The commonly used high-rate anaerobic digesters include: anaerobic filters, up flow anaerobic sludge blanket (UASB) reactors, anaerobic baffled, fluidized beds, expanded granular sludge beds (EGSB), sequencing batch reactors, anaerobic hybrid/hybrid up-flow anaerobic sludge blanket reactors and the downflow expanded granular bed reactors (DEGBR) which is a hybrid of the EGSB and static granular bed reactor (SGBR) which is shown in Figure 4 [39].

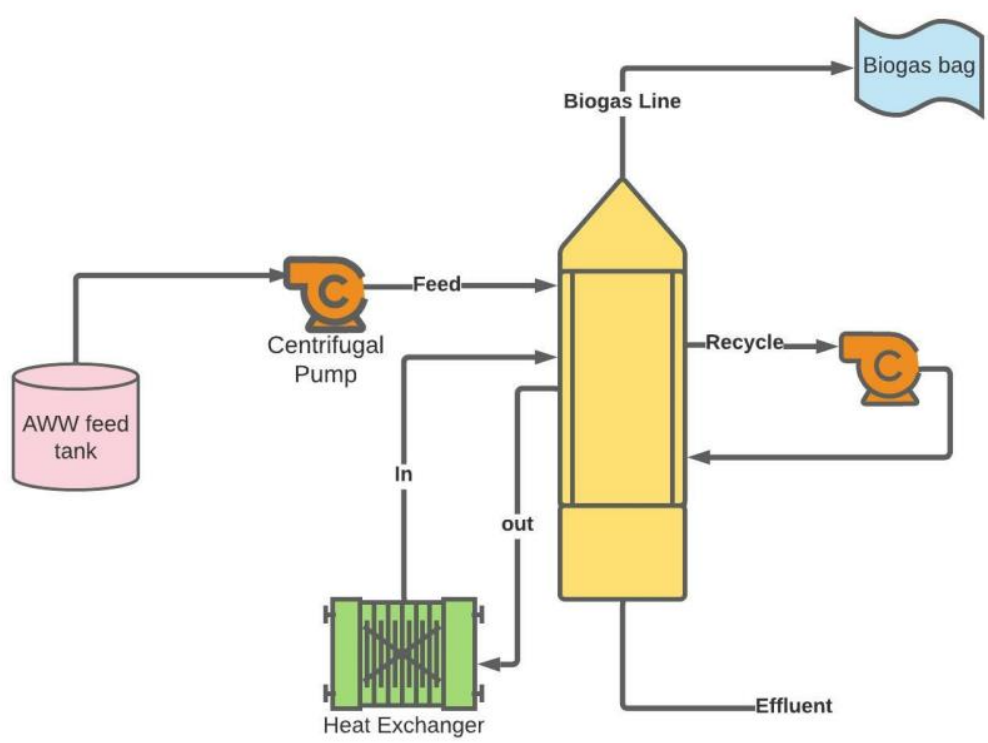

Figure 4. High-rate anaerobic reactor (Downflow Expanded Granular Bed Reactor). 
Biological processes heavily rely on the growth and bio-preservation of the required microorganisms through controlling essential operational parameters such as temperature, $\mathrm{pH}$, organic loading rate, carbon to nitrogen ratio, inoculation and start-up of the biodigester, mixing, and inhibition factors [34]. The stability of the HRABS is usually reliant on the maintenance of the mentioned operational parameters within a specific prescribed range for growth of microorganisms [33,35]. Table 2 below describes some of the inhibition parameters for anaerobic digestion and how they affect methanogenic activity.

Table 2. Inhibition factors in anaerobic digestion.

\begin{tabular}{|c|c|c|}
\hline Inhibition Parameter & Operational Range & References \\
\hline Oxygen concentration & $\begin{array}{l}\text { Oxygen concentration is measured as ORP which serves as a relative } \\
\text { quantity of oxidised materials i.e., } \mathrm{NO}_{3}^{-}, \mathrm{NH}_{4}^{+}, \mathrm{SO}_{4}{ }^{2-} \\
\text { ORP between }-200 \mathrm{mV} \text { and }-400 \mathrm{mV} \text { is ideal for anaerobic conditions. An } \\
\text { ORP of }+50 \mathrm{mV} \text { suggests a high presence of molecular oxygen and affects the } \\
\text { anaerobic microorganisms. }\end{array}$ & {$[34,35]$} \\
\hline
\end{tabular}

Psychrophilic $\left(0^{\circ} \mathrm{C}-15^{\circ} \mathrm{C}\right)$, mesophilic $\left(20^{\circ} \mathrm{C}-40{ }^{\circ} \mathrm{C}\right)$, Thermophilic

$\left(45^{\circ} \mathrm{C}-60{ }^{\circ} \mathrm{C}\right)$ and hyper thermophilic $>65^{\circ} \mathrm{C}$.

Temperature

Mesophilic and thermophilic temperatures offer better organic biodegradation and biogas production.

$[33,34,40]$

Mesophilic is most stable, requires less energy and there is less dominant ammonium inhibition as compared to thermophilic

\begin{tabular}{|c|c|c|}
\hline $\mathrm{pH}$ & $\begin{array}{c}\text { Prescribed range for anaerobic digestion is } 6.5-8 \\
\text { Hydrolysis and acetogenesis favours } \mathrm{pH} \text { range of } 5.5-6.5 \\
\text { A pH range of } 6.5-8.2 \text { favours methanogenic activity and promotes methane } \\
\text { producing bacteria i.e., methanogenium, methanolobus }\end{array}$ & {$[34,35]$} \\
\hline Nutrients concentration & $\begin{array}{c}\text { Nutrients are required to promote growth of microorganisms and results in } \\
\text { efficiency of treatment process } \\
\text { Some nutrients required are } \mathrm{N}(65 \mathrm{~g} / \mathrm{kg} \text { TSS), } \mathrm{P}(16 \mathrm{~g} / \mathrm{kg} \text { TSS), and } \mathrm{Mg} \\
(3 \mathrm{~g} / \mathrm{kg} \text { TSS }) \text { and these quantities correlate to the chemical composition of } \\
\text { the methanogenic microorganisms }\end{array}$ & [34] \\
\hline
\end{tabular}

Good methanogenic activity in HRABS results in the production of biogas and biogas production can be used as a direct measure of biodegradability efficiency. However, there were instances where a good removal of the substrate from the influent, which usually translates to a good COD or BOD5 removal percentage, didn't align with consequent production of biogas $[8,41]$. This may have been due to biogas entrapment within the anaerobic granular bed as a result of loss in kinetic energy due to friction losses, a weak connected porosity of the anaerobic granular bed or high surface tensions weakening the emergence of biogas bubbles [8,42].

Numerous studies have been carried out to develop high-rate bioreactors; however, most studies show various drawbacks, ranging from large space requirements, a massive volume of sludge generation, intensive use of energy, and the high overall cost of maintenance [11]. For instance, in the expanded granular sludge bed reactor (EGSB) and the up-flow anaerobic sludge blanket (UASB), the liquid up-flow velocity causes low and inadequate removal of nutrients, pathogens and suspended solids, which results in the requirement of post-treatment for compliance with environmental regulations [43]. Unlike the EGSB and UASB, the downflow expanded granular bed reactor (DEGBR) as shown in Figure 4, takes advantage of gravity as a supplementary force through the granular bed, hence using less energy, as there are no gravitational forces or upward frictional forces to compensate for [42]. The DEGBR consists of a recycle stream, which aids in wastewater distribution of the influent to the anaerobic biomass, and also develops a counter-current flow inside the bioreactor for enhanced mixing of its contents [42,43]. Furthermore, the downflow configuration results in the effluent being collected at the bottom and the gas naturally rising to the top, which eliminates the need for a three-phase separator to separate 
the gas and biomass compared to the UASB and EGSB [42]. Moreover, the DEGBR also has several advantages like design simplicity, low anaerobic granular sludge (AGS) production, high treatment efficiency, and low operating costs, all of which have turned this bioreactor into a sustainable alternative to mitigate the crisis of water pollution [16].

\section{Multi-Integrated Systems}

Anaerobic treatment does not produce discharge compliant effluent on its own. The complete degradation of the organic matter is difficult due to the high organic content levels in AWW, the long hydraulic retention times (HRTs) required to remove all the organics as well as the anaerobic process being slow as compared to aerobic processes. An additional treatment stage(s) is/are recommended to remove the organic matter, nutrients, and pathogens that remain after anaerobic treatment [30]. The integration of multi-stage systems can be used to remove pollutants such as heavy metals, grease and oils, color, BOD, TSS, COD and can be handled within one system with multiple stages [18]. Several studies have been done to incorporate additional stages after anaerobic digestion, as shown in Table 3. Comparing single systems and multi-stage systems shows that the latter provides higher removal efficiencies. The data from Table 3 was used to plot a graph, as shown in Figure 5.

Table 3. Comparison between effluent qualities of single systems vs. multi-integrated systems.

\begin{tabular}{|c|c|c|c|c|c|c|c|c|c|c|}
\hline \multirow[b]{2}{*}{ Process } & \multicolumn{5}{|c|}{ Influent Characteristics } & \multicolumn{5}{|c|}{ Effluent Characteristics (Removal Efficiency) } \\
\hline & $\begin{array}{l}\text { HRT } \\
\text { (h) }\end{array}$ & $\begin{array}{c}\text { TOC } \\
(\mathrm{mg} / \mathrm{L})\end{array}$ & $\begin{array}{c}\text { BOD } \\
(\mathrm{mg} / \mathrm{L})\end{array}$ & $\begin{array}{c}\mathrm{TN} \\
(\mathrm{mg} / \mathrm{L})\end{array}$ & $\begin{array}{c}\text { COD } \\
(\mathrm{mg} / \mathrm{L})\end{array}$ & $\begin{array}{c}\text { TOC } \\
(\%)\end{array}$ & $\begin{array}{c}\text { BOD } \\
(\%)\end{array}$ & TN (\%) & $\begin{array}{c}\text { COD } \\
(\%)\end{array}$ & REFERENCES \\
\hline $\begin{array}{l}\text { Anaerobic }+ \\
\text { aerobic }+ \text { uv }\end{array}$ & 96.0 & 1.0 & 640.0 & 200.0 & - & 99.98 & 99.69 & 82.84 & - & [13] \\
\hline $\begin{array}{c}\text { Anaerobic + } \\
\text { aerobic }+ \\
\text { advanced } \\
\text { oxidation }\end{array}$ & $\begin{array}{l}75.0- \\
168.0\end{array}$ & $\begin{array}{l}941.0- \\
1009.0\end{array}$ & $\begin{array}{l}630.0- \\
650.0\end{array}$ & $\begin{array}{l}254.0- \\
428.0\end{array}$ & - & $\begin{array}{l}89.5- \\
99.9\end{array}$ & 99.70 & $\begin{array}{l}76.40- \\
81.60\end{array}$ & - & [13] \\
\hline Aerobic & $3.0-96.0$ & - & - & $\begin{array}{l}1950- \\
3400\end{array}$ & $\begin{array}{l}6185- \\
6840\end{array}$ & - & - & $\begin{array}{l}8.81- \\
93.22\end{array}$ & $\begin{array}{l}9.42- \\
80.11\end{array}$ & [44] \\
\hline $\begin{array}{l}\text { Reverse } \\
\text { osmosis }\end{array}$ & - & - & 10.0 & 13.0 & 76.0 & - & 50.0 & 90.0 & 85.8 & [45] \\
\hline Anaerobic & 24 & - & $30.0-76.0$ & $6.1-27.0$ & $\begin{array}{l}49.0- \\
137.0\end{array}$ & - & 11.30 & $\begin{array}{l}42.30- \\
77.20\end{array}$ & 13.90 & [46] \\
\hline $\begin{array}{c}\text { Anaerobic }+ \\
\text { aerobic }+ \\
\text { chemical } \\
\text { coagulation }\end{array}$ & $\begin{array}{l}16.0- \\
72.0\end{array}$ & - & $\begin{array}{l}5143- \\
8360\end{array}$ & $\begin{array}{l}46.6- \\
138.0\end{array}$ & $\begin{array}{r}6363- \\
11,000\end{array}$ & - & $\begin{array}{l}97.76- \\
98.92\end{array}$ & $\begin{array}{l}73.48- \\
92.72\end{array}$ & $\begin{array}{l}50.10- \\
97.42\end{array}$ & [47] \\
\hline
\end{tabular}

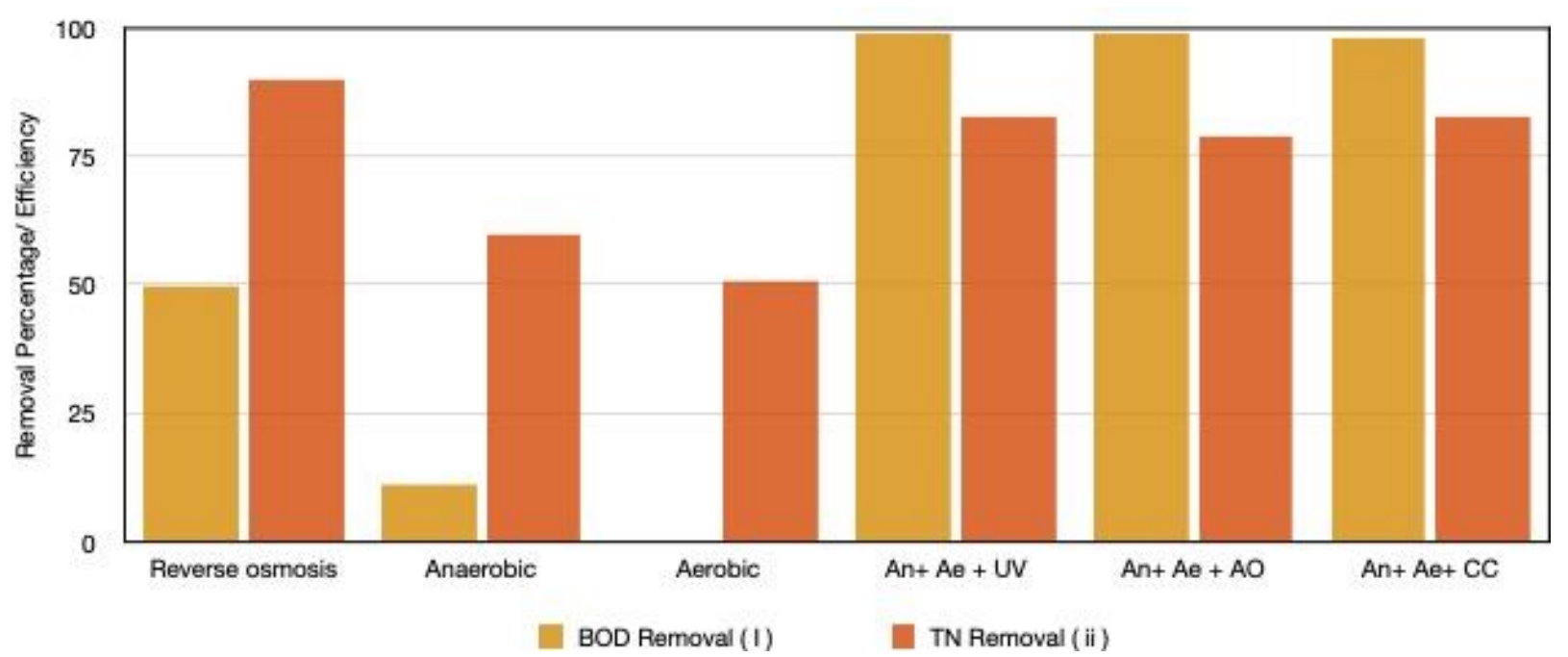

Figure 5. Comparison between single systems and MIS in removing BOD \& TN [Abbreviations: An-anaerobic process; Ae-aerobic process; $\mathrm{AO}$-advanced oxidation process, $\mathrm{CC}$-chemical coagulation]. 
Treatment technologies such as (i) membrane separation using reverse osmosis, (ii) anaerobic, (iii) aerobic, (iv) anaerobic-aerobic-UV, (v) anaerobic-aerobic advanced oxidation, and (vi) anaerobic-aerobic chemical coagulation were compared graphically to show the effect of introducing multiple stages. Figure 5 shows that all single-stage processes have a BOD removal efficiency below 50\%, whilst in multi-integrated systems, the values are above $90 \%$. The TN removal follows the same trend, with reverse osmosis having the highest efficiency despite being a single-stage process. This further supports why membranes are necessary for nutrient recovery after anaerobic digestion as a separation process. Although multi-integrated systems offer many benefits, the type of water, cost, and effluent quality will determine the number of stages and processes to be used.

The use of multi integrated systems provide a significant impact on the effluent quality. Dyosile, Mdladla [36] had a higher overall removal efficiency when an integrated system of using enzymatic pre-treatment-DEGBR-MBR was analyzed as compared to anaerobically digesting the poultry slaughterhouse wastewater (PSW) with the DEGBR with no prior or post treatment. The pre-treatment had FOG removal of $80 \%$ and the TSS and COD removal reached $38 \%$ and $56 \%$, respectively. The removal results on the DEGBR, at an OLR of 18-45 g COD/L.d, was 87\%, 93\%, and 90\% for COD, TSS, and FOG, respectively. The total removal efficiency across the pre-treatment-DEGBR-MBR units was $99 \%$ for COD, TSS, and FOG which is much higher than the single stages. Their effluent quality also met requirements for effluent discharge after post treatment using a membrane bioreactor (MBR).

A similar setup of incorporating pre-treatment-EGSB digester-MBR system was used by [32] to reduce the concentration of organic matter in PSW. The pre-treatment stage resulted in a $50 \%$ for TSS removal, $80 \%$ for COD removal, and $82 \%$ for FOG removal. The EGSB effluent had removal percentages of $90 \%$ for TSS, $>70 \%$ for COD, and $>90 \%$ for FOG. Further removal was also observed using the MBR with the removal performance being $>95 \%$ for both TSS and COD and 80\% for FOG. Their effluent after the MBR process met the discharge standards. These studies add to the fact that single stages alone do not possess the ability to treat AWW to the required discharge standards. Pre and post treatment is required with any anaerobic processes.

Figure 6 shows a proposed process flow diagram of a multi-integrated system to treat AWW. The raw wastewater is first aerobically pre-treated to remove suspended solids and FOGs and enhance anaerobic digestion. Oxygen is artificially added using an adjustable pump. A stainless-steel sieve is used to filter out any suspended solids remaining from pre-treatment. The pre-treated wastewater is added to a holding tank, which feeds into the DEGBR at the desired organic loading rate. The DEGBR operates anaerobically to biodegrade the nutrients, and biogas is produced as a by-product. The effluent from the DEGBR does not meet the required discharge standards as mentioned previously. The effluent becomes the feed to the membrane bioreactor (MBR) where nitrification and denitrification takes place. The micropollutants that pass through membranes can be disinfected using the ultraviolet system (UV). Bustillo-Lecompte, Mehrvar [13] and Bustillo-Lecompte and Mehrvar [30] demonstrate an evaluation on treating AWW using combined advanced oxidation processes. The evaluation factored in treatment capability and overall costs for treatment technologies, including ABR, AS and UV. It was proven that the combined process of the ABR-AS-UV system was the most cost-effective solution compared to single processes for TOC removal under optimal conditions. However, as this may be a guide, different wastewaters have different characteristics, and analysis must be done to find the best method possible.

Ultraviolet (UV) light is frequently used for pathogen inactivation in wastewater treatment [48-51]. UV light effectively inactivates viruses, bacteria, and cysts by penetrating cell walls and damaging DNA or RNA without chemical addition. Traditional UV lamps are low-cost and accessible in developing economies, but also contain toxic mercury vapor. On the other hand, UV LEDs are more expensive but mercury-free [1,52]. 


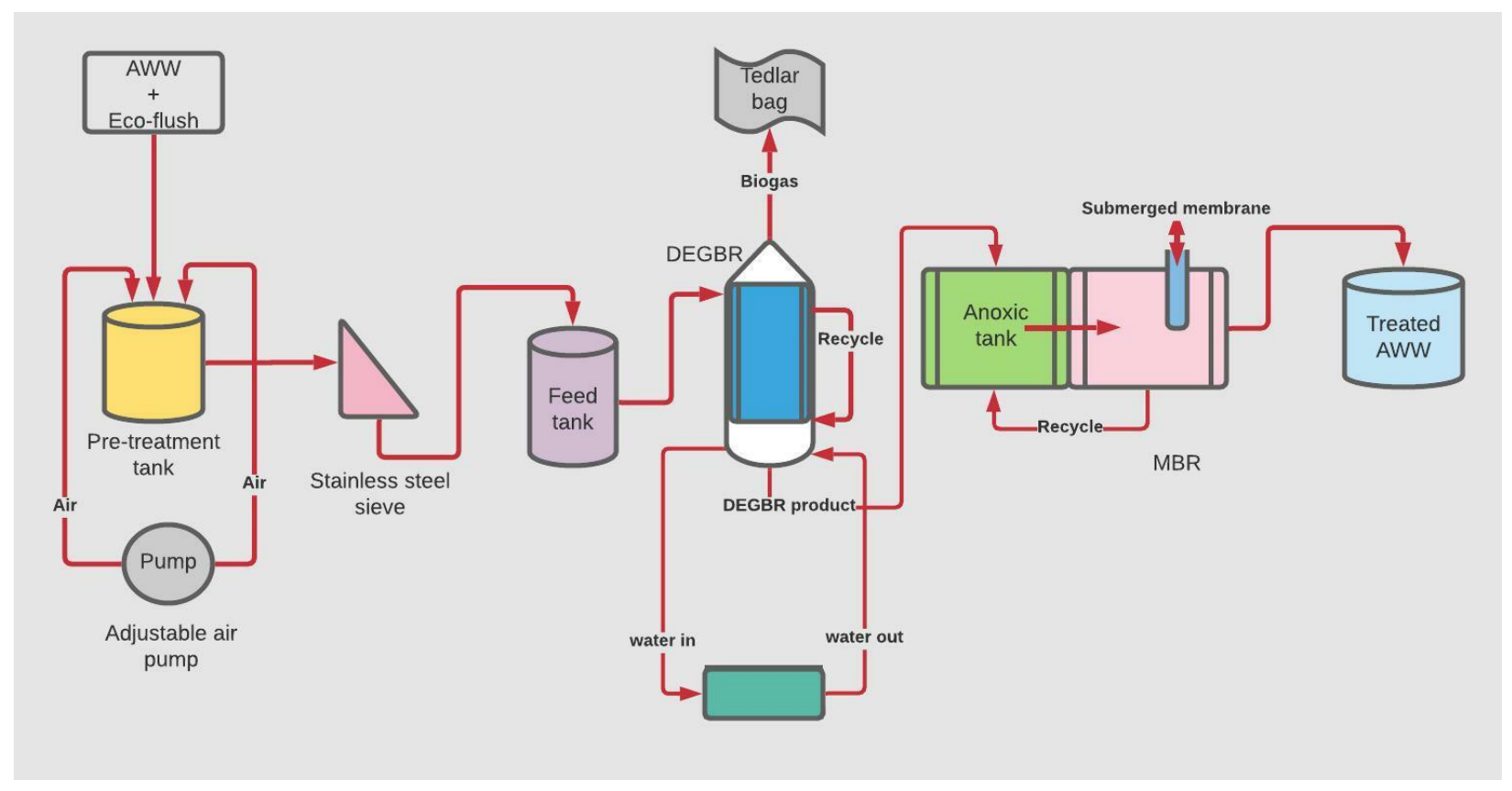

Figure 6. Process flow diagram of a proposed multi-stage integrated system to treat AWW.

The study by Beck, Suwan [1] evaluated a cost-effective, user-friendly, and relatively fast treatment process involving a woven-fiber microfiltration (WFMF) membrane to filter domestic wastewater followed by UV disinfection to disinfect the permeate. With an effective pore size of 1-3 $\mu \mathrm{m}$ [53] the membrane was capable of removing Ascaris lumbricoides eggs $(50 \mathrm{~mm})$ and Giardia cysts $(10 \mu \mathrm{m})$, whereas bacteria $(1-2 \mu \mathrm{m})$, viruses, and Cryptosporidum oocysts $(3 \mu \mathrm{m})$, which are small enough to pass through the filter pores, were inactivated by exposure to UV light. The bacteria (total coliform and Escherichia coli) and viruses (MS2 bacteriophage) passing through the membrane were disinfected by flow-through UV reactors containing either a low-pressure mercury lamp or light-emitting diodes (LEDs) emitting an average peak wavelength of $276 \mathrm{~nm}$. For domestic wastewater from a university campus that they used in their study, the membrane reduced TSS (by $79.8 \%$ ), turbidity by $76.5 \%$, COD by $38.5 \%$, BOD by $47.8 \%$, and $\mathrm{NO}_{3}$ by $41.4 \%$. UVT at $254 \mathrm{~nm}$ improved by $19.4 \%$, and UVT at $280 \mathrm{~nm}$ by $12.4 \%$ [1]. Following UV disinfection, wastewater quality met the WHO standards for unrestricted irrigation. UV lambs can succumb to fouling and scaling after extensive use and it is reversible through citric acid circulation [54].

\section{Hybrid Membrane Bioreactor}

A membrane bioreactor (MBR) is an integrated system with membrane filtration for the biological degradation of waste present in wastewater. Generally, it is composed of a biological unit and a membrane module, which separates water from the aerobically digested water and returns activated sludge to the biological unit [55].

Anaerobic membrane bioreactors (AnMBRs) retain solids selectively through microfiltration membranes which offer an alternative to lagoons and granule based high-rate anaerobic treatments [56]. They produce an excellent effluent quality, have a high tolerance to OLR variations, as well as the ability to produce a solid free effluent for the purposes of reuse [57]. The hybrid membrane bioreactor consists of (i) an anoxic stage and (ii) an aerobic membrane filtration stage. Since the DEGBR operates anaerobically, it has two significant drawbacks, (i) it is ineffective in removing nitrates and phosphorous, and (ii) it reduces the organic nitrogen and sulphur to ammonia and hydrogen sulphide, which are toxic, hence the need for incorporating a membrane bioreactor stage as post-treatment. The advantages of MBR compared with a conventional activated sludge process include high effluent 
quality, decreased reactor volume, elevated solid retention time (SRT) and high mixed liquor suspended solids (MLSS), low sludge yield, and easier operation [58,59]. However there are still some drawbacks associated with MBRs such as; membrane fouling, high energy consumption and low removal efficiency of poorly biodegradable micropollutants like diclofenac, atrazine, and carbamazepine [58].

MBR technology has been widely used recently for nutrient recovery. Coagulation or flocculation can be used to recover valuable nutrients in the conventional process. Unfortunately, the protein concentrate obtained by the traditional methods cannot be used as animal food because coagulants and flocculants can introduce some harmful compounds and change protein properties. Pressure-driven membrane processes are good at protein recovery while keeping protein unchanged since membrane separation is a physical process [55].

Recovering nutrients from wastewater reduces the environmental effects of wastewater treatment, and subsequently, the recovered nutrients can be used to produce fertilizers. Phosphorus and nitrogen are essential for organism growth and result in eutrophication in surface water sources, leading to the death of aquatic life [56]. If ammonium and phosphate ions were to be removed from wastewater using processes such as chemical precipitation, it would consume a large amount of electricity and cost about $4 \%$ extra compared to nutrient recovery [60]. Besides the extra costs involved, nutrient recovery is better than complete removal because i) nutrient-based fertilizers can be produced for agricultural purposes, (ii) the environmental impact from wastewater discharged is reduced, hence less eutrophication occurs, and iii) $\mathrm{N}$ recovery can reduce the consumption of natural resources and save costs on nitrogen fixation [56].

The hybrid membrane bioreactor is required to provide an anoxic-aerobic stage where oxygen is utilized by bacteria to oxidize the ammonia and hydrogen sulphide to less harmful substances. Nitrification occurs due to two specific autotrophic bacteria, the ammonia oxidising organisms (ANOs) and the nitrite oxidising organisms (NNOs), and occurs in two steps. The ANOs convert free and saline ammonia to nitrite. In the second step, the NNOs convert nitrite to nitrate. Ammonia and nitrite are used for catabolism [33]. Nitrification is a prerequisite for denitrification, and without it, biological $\mathrm{N}$ removal is not possible. Denitrification becomes possible once nitrification takes place by incorporating anoxic zones in the reactor. The denitrification occurs anoxically via facultative heterotrophic biomass [33]. During nitrification, the $\mathrm{N}$ remains in the liquid phase because it is transformed from ammonia to nitrate. In the denitrification step, the $\mathrm{N}$ is transferred from the liquid to the gas phase and escapes to the atmosphere.

The proposed study referred to in Figure 7 employs the modified Ludzack-Ettinger system (MLE), which separates the anoxic and aerobic reactors by putting them in series, as shown in Figure 7 below. It also consists of a recycle for the underflow feeding back to the first anoxic reactor as well as a mixed liquor recycle from the aerobic to the primary anoxic reactor. The influent is discharged to the first or primary anoxic reactor, which is maintained in an anoxic state by mixing without aeration and provides conducive conditions for denitrification. The second reactor is aerated and is where nitrification takes place. However, the MLE system has one major drawback: complete nitrate removal cannot be achieved because a part of the total flow from the aerobic reactor is not recycled to the anoxic reactor but instead exits the system with the effluent [33].

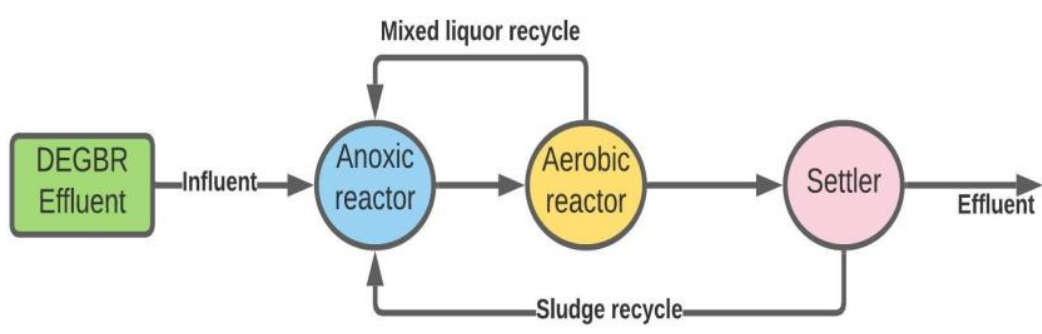

Figure 7. MLE system for nitrification and denitrification. 
Phosphorus can be removed biologically through enhanced biological phosphorus removal, exploiting the ability of polyphosphate-accumulating organisms (PAOs) to take up $P$ in excess of metabolic requirements and accumulate it intracellularly as polyphosphate [61]. This metabolic phenotype is facilitated by a continuing cycle of provision of organic carbon, mainly in the form of volatile fatty acids (VFAs) to the microorganisms, and then exposure of the organisms to first anaerobic and then aerobic conditions. Organic carbon is often the limiting substrate for both denitrification and P removal, and many wastewater treatment plants add extra carbon for denitrification to balance the processes. A combination of denitrification and enhanced biological phosphorus removal in one process could offer substantial savings on carbon for the overall nutrient removal process, which makes this approach highly attractive [62].

The performance of the membrane is mainly characterized by the permeate flux and retention properties [5]. Membrane separation has one particular advantage over other separation processes such as distillation, crystallization and adsorption because it relies on physical separation without phase change and usually no addition of chemicals. Therefore, energy consumption is usually much lower compared to distillation and crystallization [63]. Two main MBR configurations exist: side stream and submerged, as shown in Figure 8. A recirculation pump provides cross-flow velocity in the side stream configuration to reduce blockage by suspended solids on the membrane surface. The side stream MBR is widely used in industrial wastewater treatment but has a higher energy demand. On the other hand, the submerged MBR operates at lower flux and offers higher permeability. They are often used in municipal wastewater treatment. Coarse aeration is provided to the system to reduce fouling as well as provide oxygen to the biomass [64].

(a)

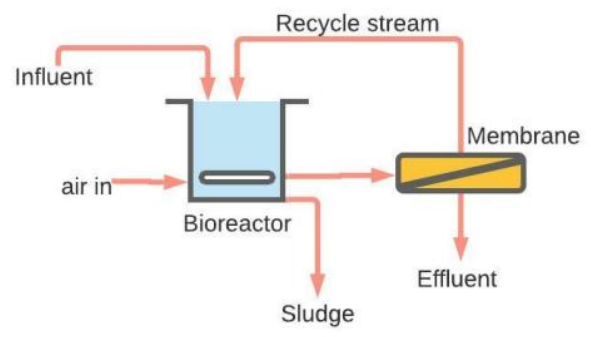

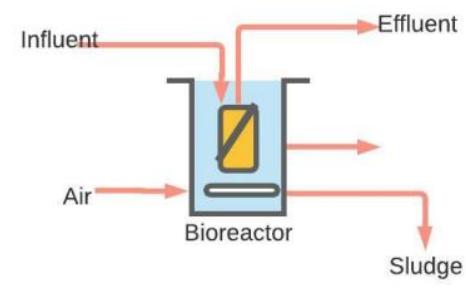

Figure 8. AnMBR configurations: (a) side stream configuration, (b) submerged configuration.

\section{Applications of Membranes in Wastewater Treatment}

Pressure-driven membrane processes such as microfiltration (MF), ultrafiltration (UF), reverse osmosis (RO), and nanofiltration (NF) are widely studied for wastewater treatment and they rely on hydraulic pressure to achieve separation [65]. Membrane filtration is one of the most emerging technologies to produce high-quality water because it utilizes zero chemical constituents and offers enormous advantages over conventional methods [55]. Mostly used membrane filtration in wastewater treatments are RO, UF and MF. Although reverse osmosis (RO) is a well-established technology for water reuse and desalination $[66,67]$ it is still limited by its high energy consumption and operating costs as the flow is against the pressure gradient.

An alternative is the use of low-pressure RO (LPRO) membranes which have been developed to reduce the RO operation pressure when maintaining high rejections to small soluble organic molecules and ionic species [68-70]. The operation pressure is an important operation parameter of LPRO, which affects the filtration productivity (flux), membrane fouling, and energy consumption. The performance of $\mathrm{RO}$ in the treatment of secondary effluent of SWW was reported by [45] to remove organic matter and the removal efficiencies of $\mathrm{BOD}, \mathrm{COD}, \mathrm{TN}$, and TP were found to be 50.0, 85.8, 90.0, and $97.5 \%$, respectively. It was concluded that LPRO was a suitable technique for the post-treatment of AWW effluent. 
A study done by [71] on the performance of the UF membrane treating AWW showed BOD and COD removal efficiencies of around $97.8-97.89 \%$ to $94.52-94.74 \%$, whereas TSS and FOG removal were $98 \%$ and $99 \%$, respectively [72]. Pressure driven membrane processes have proven to be successful in the separation of valuable organic and inorganic compounds in black liquor as well as being energy-efficient in several studies [73-75]. In recent studies, separation processes are being coupled to improve effluent quality. For example, UF/NF combinations have been reported to be a promising solution in wastewater with high amounts of organic material such as black liquor. In these cases, UF is used as a pre-treatment for NF [73,76].

The ultrafiltration (UF) pre-treatment and the control of the operation pressure were found to be essential for mitigating LPRO membrane fouling. Water quality analyses showed that an integrated process of the UASB + UF + LPRO could achieve an effluent quality characterized by concentrations of 10.4-12.5 mg/L of chemical oxygen demand (COD), $1.8-2.1 \mathrm{mg} / \mathrm{L}$ of total nitrogen (TN), 1.3-1.8 mg/L of ammonia nitrogen (NH3-N), and $0.8-1.2 \mathrm{mg} / \mathrm{L}$ of total phosphorus (TP) [70].

Coskun, Debik [77] studied the PSW treatment using laboratory-scale membrane processes. Their study reported that UF as pretreatment improved the removal efficiencies for NF and RO processes; NF reduced almost $90 \%$ of COD, RO removed $97.4 \%$ of COD, and the UF pretreatment resulted in higher final fluxes 8.1 and 5.7 times more for NF and $R O$, respectively, than for those without UF.

Ionic species can be removed to meet the reuse requirements of brewery wastewater effluent discharge by the inclusion of reverse osmosis into the treatment chain $[66,70]$. Verhuelsdonk, Glas [78] did an economic analysis on brewery wastewater reuse and reported that UASB wastewater could be treated to drinking water quality with a yield of $63 \%$ by using an MBR + UF + RO system.

A comparison study was done by Skoczko, Puzowski [59] to compare the modernized vs conventional treatment methods on a newly modernized wastewater treatment plant. On the basis of the conducted research, it was noted that the operation of the plant after modernization was more cost-intensive. There were additional electricity costs due to ensuring adequate pressure on the membranes. Nevertheless, the obtained results of the removal of contaminants showed BOD removal of over $99.0 \%$, COD removal of $99.0 \%$, TSS removal of $99.5 \%$, and removal degree of biogenic compounds also increased and exceeded $98 \%$. Although the membranes have been well researched and are still being improved, it continues to show high operational costs due to aeration and membrane fouling, which constitutes a major drawback.

\section{Membrane Preservation, Fouling and Cleaning Methods}

The accumulation of particulates such as fats, grease, protein, and organic matter can cause build-up on the membrane material resulting in membrane fouling and wetting which is a huge economic influence on the use of membranes as they account for $72 \%$ of the capital investment [10]. The types of foulants which may interfere with membrane performance include chemical foulants such as scaling, physical foulants such as deposition of particles, biological foulants such as microbes, and organic foulants which interact with the membrane material [79]. Membrane wetting is the process in which membrane materials lose their hydrophobicity and allow for liquids to penetrate the membrane pores resulting in a direct liquid flow from feed through the wetted pores, substantially deteriorating permeate quality [79]. The fouling and wetting of membrane materials impairs the membrane performance and shortens membrane lifetime, thereby reducing $\mathrm{NH} 3$ recovery from AWW.

To reduce fouling and wetting, membranes can be cleaned. Several chemical and physical cleaning methods were developed to remove membrane fouling. The membrane cleaning process is affected by different factors. The type and mode of cleaning for example, physical cleaning, doesn't really retrieve membrane permeability effectively as it only removes loose particles. Temperature is considered as another factor that may take effect 
on the membrane cleaning strategy. Increasing temperature is substantial for cleaning the fouling membrane by increasing solubility due to reactivity of functional groups at high temperatures of the organic matters and increasing mass transfer dispersion with mechanical destabilization of biofilm layers on the membrane surface [58]. Increasing the $\mathrm{pH}$ also has a directly proportional relationship with membrane cleaning efficiency [80]. For instance, increasing $\mathrm{pH}$ from $4.9-11.0$ will affect the cleaning percentage from $25 \%-44 \%$ and, at $\mathrm{pH} 11$, it is very easy to break down the gel layer on the membrane surface when compared to the lower $\mathrm{pH}$ [58]. Table 4 below shows some of the membrane cleaning methods used to reduce fouling and improve membrane life in membrane technology.

Table 4. Membrane cleaning methods used in membrane technology.

\begin{tabular}{|c|c|c|c|c|}
\hline Industry & Membrane Process Type & Chemicals Used & Result & Reference \\
\hline $\begin{array}{l}\text { Municipal } \\
\text { (drinking water } \\
\text { treatment } \\
\text { systems) }\end{array}$ & Ultrafiltration (UF) & $\begin{array}{c}\text { Membrane vibration }+ \\
\text { coagulation. coagulants, such } \\
\text { as } \mathrm{Al} \text { (III) and Fe (III) } \\
\text { compounds, were added to } \\
\text { the influent }\end{array}$ & $\begin{array}{l}\text { Membrane rotation speed of } 60 \mathrm{r} / \mathrm{min} \text {, the } \\
\text { permeate flux increased by } 90 \% \text { and the } \\
\text { organic removal by } 35 \% \text {, with a } 40 \mathrm{mg} / \mathrm{L} \\
\text { coagulant dosage, with an additional } 70 \% \\
\text { increase of flux and a } 5 \% \text { increment of } \\
\text { organic removal to } 80 \% \text { was obtained. }\end{array}$ & {$[81]$} \\
\hline $\begin{array}{l}\text { Food industry } \\
\text { (fruit juice } \\
\text { concentration) }\end{array}$ & Forward Osmosis & $\begin{array}{l}\text { Pretreatment by } \\
\text { microfiltration before FO } \\
\text { process }\end{array}$ & $\begin{array}{l}\text { There was an attractive interaction between } \\
\text { the FO membrane and orange juice foulants. } \\
\text { Eliminating those foulants using the } \\
\text { microfiltration pre-treatment weakened such } \\
\text { an attractive interaction and effectively } \\
\text { prevented the fouling layer from growing, } \\
\text { leading to a lower process resistance and, } \\
\text { finally, resulting in a great improvement of } \\
\text { concentration efficiency }\end{array}$ & [82] \\
\hline Food industry & $\begin{array}{l}\text { Electrodialysis with } \\
\text { bipolar membranes } \\
\text { (EDBM) }\end{array}$ & $\begin{array}{l}\text { Pulsed electric field (PEF) } \\
\text { mode, which consists in the } \\
\text { application of constant } \\
\text { current density pulses during } \\
\text { a fixed time (Ton) alternated } \\
\text { with pause lapses (Toff) }\end{array}$ & $\begin{array}{l}\text { Both a long pause and high flow rate } \\
\text { contribute to a more effective decrease in the } \\
\text { concentration of protons and caseinate } \\
\text { anions at the BPM surface: a very good } \\
\text { membrane performance was achieved with } \\
50 \text { s of pause duration of PEF and a flow rate } \\
\text { corresponding to Reynolds number }=374\end{array}$ & [83] \\
\hline $\begin{array}{l}\text { Municipal } \\
\text { wastewater }\end{array}$ & $\begin{array}{c}\text { Membrane } \\
\text { Bio-Reactors (MBRs) }\end{array}$ & $\begin{array}{l}\text { Examines the effect of } \\
\text { operating conditions on } \\
\text { fouling of membrane } \\
\text { Bio-Reactors (MBRs). } \\
\text { Conditions such as: } \\
\text { diminishing DO, recirculating } \\
\text { rate and controlled growth of } \\
\text { filamentous microorganisms } \\
\text { were optimised }\end{array}$ & 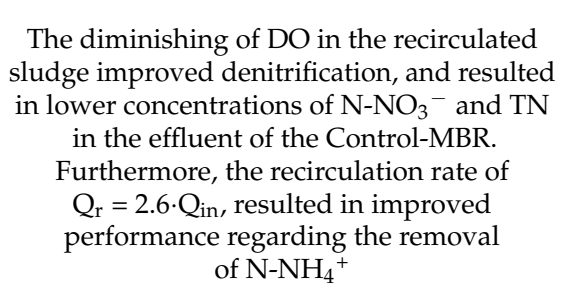 & {$[84]$} \\
\hline $\begin{array}{l}\text { Second effluent of } \\
\text { sewage with } \\
\text { Activated sludge }\end{array}$ & $\mathrm{FO}$ & $\begin{array}{l}\text { Physical cleaning Air } \\
\text { scouring }\end{array}$ & - & [85] \\
\hline PSW & $\mathrm{UF}, \mathrm{MF}$ & $\begin{array}{l}\text { Sodium hypochlorite, citric } \\
\text { acid, sodium hydroxide, and } \\
\text { ultrapure water }\end{array}$ & Recovered $95 \%$ of water flux & {$[5]$} \\
\hline PSW & UF & $\begin{array}{c}\text { Electrocoagulation } \\
\text { pre-treatment }\end{array}$ & $\begin{array}{l}\text { Pre-treatment approaches can be adopted to } \\
\text { alleviate fouling before the membrane } \\
\text { filtration process. }\end{array}$ & {$[86]$} \\
\hline
\end{tabular}

Recommendations and future perspectives:

1. There are numerous NF membranes available in the market, but only some of them can resist harsh operating conditions (such as extreme $\mathrm{pH}$ ) [73]. Further studies can be carried out to produce membranes that are stable and not susceptible to fouling in high $\mathrm{pH}$ conditions.

2. For high quality effluents, a novel MBR called the osmosis membrane bioreactor (OMBR) has been developed to promote wastewater treatment and reuse [58]. In $\mathrm{OMBR}$, the FO membrane module is displaced in the wastewater. Combined with 
biological treatment, water from the mixed liquor is forced to transfer through the semipermeable membrane to the draw side under the osmotic pressure gradient. The pollutants, activated sludge, and solids are all rejected by the membrane. The superior performance of OMBR over conventional MBR has been demonstrated in previous research [58]. This OMBR can be integrated into the proposed system of this review instead of UF. This will reduce overall running costs incurred through high energy consumption, the cost for chemical cleaning, and membrane life which are limitations in pressure-driven membrane processes.

3. Several studies reported that chemical cleaning could achieve highly efficient membrane cleaning from organic foulants, which may have a strong interaction with the membrane surface [87-90]. Although chemical cleaning is a viable option, it does not provide the eco-friendliness and biological treatment options the world is moving towards and this might cause an environmental problem as the effluent stream may be discharged containing chemicals. Hence more physio-biological pretreatment options and parameter optimization can be a way to ensure limited fouling and maintain a minimal pollution footprint.

\section{Conclusions}

Whilst biological processes such as anaerobic and aerobic digestion provide the muchneeded benefits of being environmentally friendly and economical, they still fall short in nutrient removal, digesting FOGs, and removing suspended solids. The choice of reactor also affects the composition of effluent, the costs incurred during operation, and the space required. Anaerobic digestion is very sensitive, involving different bacterial groups (methanogenic, acetogenic, etc.), which all have different optimum conditions. These bacteria are inhibited by process parameters such as temperature, $\mathrm{pH}$, VFA concentrations, etc. Therefore, it is paramount to maintain stable operating conditions in the digester. The DEGBR gives numerous advantages, such as ease of operation, and lowers energy requirements for pumping, as the water is aided by gravity and also provides turbulent mixing through the recycled stream. In contrast, the up-flow reactors such as the EGSB and the UASB experience poor reactor performance caused by a high up-flow velocity, biomass washout and higher energy requirements to oppose gravity and compensate for head losses to friction. The DEGBR has become more favorable for treating high strength wastewater. Adding a pre-treatment stage before anaerobic digestion, where enzymes are used to hydrolyze and break down FOGs increases biogas production, improves reactor performance, and results in ease of operation. Other post anaerobic digestion treatment stages such as nitrification, denitrification, membrane filtration, and ultraviolet radiation can be added to improve the removal efficiency of $\mathrm{P}, \mathrm{C}$, and N, as well as help meet the regulation standards.

Author Contributions: Writing—original draft preparation, L.G.; Supervision, M.B.; Funding acquisition, M.B.; Writing—review and editing, M.B. \& L.G.; Reviewing-T.H., D.I., C.G., and M.N. All authors have read and agreed to the published version of the manuscript.

Funding: This research was funded by National Research Foundation, Thuthuka Funding, R017, the Cape Peninsula University of Technology University Research Fund (URF), and the Bioresource Engineering Research Group (CPUT, BioERG) subsidy cost centers RK45 and R971.

Acknowledgments: The authors wish to acknowledge the National Research Foundation Thuthuka Funding, R017, for their financial contribution to this work, the South African Breweries (SAB).

Conflicts of Interest: The authors declare no conflict of interest.

$\begin{array}{ll}\text { Abbreviations } \\ \text { COD } & \text { Chemical oxygen demand } \\ \text { BOD } & \text { Biological oxygen demand } \\ \text { TSS } & \text { Total suspended solids } \\ \text { VSS } & \text { Volatile suspended solids }\end{array}$




$\begin{array}{ll}\text { DEGBR } & \text { Downflow expanded granular bed reactor } \\ \text { EGSB } & \text { Expanded granular sludge bed reactor } \\ \text { AnMBR } & \text { Anaerobic membrane bioreactor } \\ \text { VFA } & \text { Volatile fatty acids } \\ \text { FOG } & \text { Fats oils and grease } \\ \text { WQI } & \text { Water quality index } \\ \text { TDS } & \text { Total dissolved solids } \\ \text { UASB } & \text { Up-flow anaerobic sludge bed } \\ \text { PSW } & \text { Poultry slaughterhouse wastewater } \\ \text { HRABS } & \text { High rate anaerobic bioreactors } \\ \text { AGS } & \text { Anaerobic granular sludge } \\ \text { HRT } & \text { Hydraulic retention time } \\ \text { OLR } & \text { Organic loading rate } \\ \text { UV } & \text { Ultraviolet } \\ \text { SRT } & \text { Solids retention time } \\ \text { MLSS } & \text { Mixed liquor suspended solids } \\ \text { ANOs } & \text { Ammonia oxidising organisms } \\ \text { NNOs } & \text { Nitrite oxidising organisms } \\ \text { MLE } & \text { Modified Ludzack Ettinger } \\ \text { PAO } & \text { Phosphorus accumulating organisms } \\ \text { LPRO } & \text { Low pressure reverse osmosis } \\ \text { RO } & \text { Reverse osmosis } \\ \text { UF } & \text { Ultrafiltration } \\ \text { MF } & \text { Microfiltration } \\ \text { FO } & \text { Forward osmosis } \\ \text { OMBR } & \text { Osmosis membrane bioreactor } \\ \text { EDBM } & \text { Electrodialysis bipolar membrane } \\ \text { NF } & \text { Nanofiltration } \\ & \end{array}$

\section{References}

1. Beck, S.E.; Suwan, P.; Rathnayeke, T.; Nguyen, T.M.H.; Huanambal-Sovero, V.A.; Boonyapalanant, B.; Hull, N.M.; Koottatep, T. Woven-Fiber Microfiltration (WFMF) and Ultraviolet Light Emitting Diodes (UV LEDs) for Treating Wastewater and Septic Tank Effluent. Water 2021, 13, 1564. [CrossRef]

2. Abdelhay, A.; Othman, A.A.; Albsoul, A. Treatment of slaughterhouse wastewater using high-frequency ultrasound: Optimization of operating conditions by RSM. Environ. Technol. 2020, 1-9. [CrossRef]

3. Barbut, S. The Science of Poultry and Meat Processing; University of Guelph: Guelph, ON, Canada, 2015; pp. 1-704.

4. Aziz, H.A.; Puat, N.N.A.; Alazaiza, M.Y.D.; Hung, Y.-T. Poultry Slaughterhouse Wastewater Treatment Using Submerged Fibers in an Attached Growth Sequential Batch Reactor. Int. J. Environ. Res. Public Health 2018, 15, 1734. [CrossRef] [PubMed]

5. Marchesi, C.M.; Paliga, M.; Oro, C.E.D.; Dallago, R.M.; Zin, G.; Di Luccio, M.; Oliveira, J.V.; Tres, M.V. Use of membranes for the treatment and reuse of water from the pre-cooling system of chicken carcasses. Environ. Technol. 2021, 42, 126-133. [CrossRef] [PubMed]

6. Farzadkia, M.; Vanani, A.; Golbaz, S.; Sajadi, H.; Bazrafshan, E. Characterization and evaluation of treatability of wastewater generated in Khuzestan livestock slaughterhouses and assessing of their wastewater treatment systems. Glob. Nest J. 2016, 18, 108-118.

7. Rabah, F. Physical, Chemical and Biological Characteristics of Waste Water. In Advanced Sanitary Engineering; The Islamic University of Gaza: Gaza, Palestine, 2018; Available online: http:/ / site.iugaza.edu.ps/halnajar/files/2010/02/unit-1.-Itroduction-towastewater-treatment.pdf.

8. Basitere, M. Performance Evaluation of an up-and down-flow Anaerobic Reactor for the Treatment of Poultry Slaughterhouse Wastewater in South Africa. Ph.D. Thesis, Cape Peninsula University of Technology, Cape Town, South Africa, 2017.

9. Aziz, A.; Basheer, F.; Sengar, A.; Irfanullah, A.; Khan, S.U.; Farooqi, I.H. Biological wastewater treatment (anaerobic-aerobic) technologies for safe discharge of treated slaughterhouse and meat processing wastewater. Sci. Total Environ. 2019, 686, 681-708. [CrossRef] [PubMed]

10. Brennan, B.; Gunes, B.; Jacobs, M.R.; Lawler, J.; Regan, F. Potential Viable Products Identified from Characterisation of Agricultural Slaughterhouse Rendering Wastewater. Water 2021, 13, 352. [CrossRef]

11. Musa, M.A.; Idrus, S.; Che Man, H.; Nik Daud, N.N. Performance Comparison of Conventional and Modified Upflow Anaerobic Sludge Blanket (UASB) Reactors Treating High-Strength Cattle Slaughterhouse Wastewater. Water 2019, 11, 806. [CrossRef]

12. Chen, Y.; Cheng, J.J.; Creamer, K.S. Inhibition of anaerobic digestion process: A review. Bioresour. Technol. 2008, 99, 4044-4064. [CrossRef] 
13. Bustillo-Lecompte, C.F.; Mehrvar, M.; Quiñones-Bolaños, E. Combined anaerobic-aerobic and $\mathrm{UV} / \mathrm{H}_{2} \mathrm{O}_{2}$ processes for the treatment of synthetic slaughterhouse wastewater. J. Environ. Sci. Health Part A 2013, 48, 1122-1135. [CrossRef]

14. Ozdemir, S.; Yetilmezsoy, K. A mini literature review on sustainable management of poultry abattoir wastes. J. Mater. Cycles Waste Manag. 2020, 22, 11-21. [CrossRef]

15. Damasceno, F.R.; Cavalcanti-Oliveira, E.D.; Kookos, I.K.; Koutinas, A.A.; Cammarota, M.C.; Freire, D.M. Treatment of wastewater with high fat content employing an enzyme pool and biosurfactant: Technical and economic feasibility. Braz. J. Chem. Eng. 2018, 35, 531-542. [CrossRef]

16. Basitere, M.; Njoya, M.; Ntwampe, S.K.O.; Sheldon, M.S. Up-flow vs downflow anaerobic digester reactor configurations for treatment of fats-oil-grease laden poultry slaughterhouse wastewater: A review. Water Pract. Technol. 2020, 15, 248-260. [CrossRef]

17. Liew, Y.X.; Chan, Y.J.; Manickam, S.; Chong, M.F.; Chong, S.; Tiong, T.J.; Lim, J.W.; Pan, G.-T. Enzymatic pretreatment to enhance anaerobic bioconversion of high strength wastewater to biogas: A review. Sci. Total Environ. 2020, 713, 136373. [CrossRef] [PubMed]

18. Meiramkulova, K.; Zorpas, A.A.; Orynbekov, D.; Zhumagulov, M.; Saspugayeva, G.; Kydyrbekova, A.; Mkilima, T.; Inglezakis, V.J. The Effect of Scale on the Performance of an Integrated Poultry Slaughterhouse Wastewater Treatment Process. Sustainability 2020, 12, 4679. [CrossRef]

19. Zhang, S.; Zou, L.; Wan, Y.; Ye, M.; Ye, J.; Li, Y.-Y.; Liu, J. Using an expended granular sludge bed reactor for advanced anaerobic digestion of food waste pretreated with enzyme: The feasibility and its performance. Bioresour. Technol. 2020, 311, 123504. [CrossRef]

20. Mondal, T.; Jana, A.; Kundu, D. Aerobic wastewater treatment technologies: A mini. Int. J. Env. Tech. Sci. 2017, 4, 135-140.

21. Affes, M.; Aloui, F.; Hadrich, F.; Loukil, S.; Sayadi, S. Effect of bacterial lipase on anaerobic co-digestion of slaughterhouse wastewater and grease in batch condition and continuous fixed-bed reactor. Lipids Health Dis. 2017, 16, 195. [CrossRef] [PubMed]

22. Carrère, H.; Dumas, C.; Battimelli, A.; Batstone, D.J.; Delgenès, J.P.; Steyer, J.P.; Ferrer, I. Pretreatment methods to improve sludge anaerobic degradability: A review. J. Hazard. Mater. 2010, 183, 1-15. [CrossRef]

23. Pilli, S.; Yan, S.; Tyagi, R.D.; Surampalli, R.Y. Thermal Pretreatment of Sewage Sludge to Enhance Anaerobic Digestion: A Review. Crit. Rev. Environ. Sci. Technol. 2015, 45, 669-702. [CrossRef]

24. Doosti, M.; Kargar, R.; Sayadi, M. Water treatment using ultrasonic assistance: A review. Proc. Int. Acad. Ecol. Environ. Sci. 2012, 2, 96-110.

25. Sanghamitra, P.; Mazumder, D.; Mukherjee, S. Treatment of wastewater containing oil and grease by biological method-A review. J. Environ. Sci. Health Part A 2021, 56, 394-412. [CrossRef] [PubMed]

26. Nakhla, G.; Farooq, S. Simultaneous nitrification-denitrification in slow sand filters. J. Hazard. Mater. 2003, 96, 291-303. [CrossRef]

27. Bora, M.; Goswami, D.C. Water quality assessment in terms of water quality index (WQI): Case study of the Kolong River, Assam, India. Appl. Water Sci. 2017, 7, 3125-3135. [CrossRef]

28. Nguyen, V.K.; Kumar Chaudhary, D.; Hari Dahal, R.; Hoang Trinh, N.; Kim, J.; Chang, S.W.; Hong, Y.; Duc La, D.; Nguyen, X.C.; Hao Ngo, H.; et al. Review on pretreatment techniques to improve anaerobic digestion of sewage sludge. Fuel 2021, 285, 119105. [CrossRef]

29. Yuan, Y.; Hu, X.; Chen, H.; Zhou, Y.; Zhou, Y.; Wang, D. Advances in enhanced volatile fatty acid production from anaerobic fermentation of waste activated sludge. Sci. Total Environ. 2019, 694, 133741. [CrossRef]

30. Bustillo-Lecompte, C.; Mehrvar, M. Slaughterhouse wastewater: Treatment, management and resource recovery. In PhysicoChemical Wastewater Treatment Resource Recovery; Farroq, R., Ahmad, Z., Eds.; Intech: Rijeka, Croatia, 2017; pp. $153-174$.

31. Ergofito. Ecoflush Eliminated Ammonia. Ecoflush Eliminated Odours. Available online: https://www.ergofito.co.za/home (accessed on 25 July 2021).

32. Meyo, H.B.; Njoya, M.; Basitere, M.; Ntwampe, S.K.O.; Kaskote, E. Treatment of Poultry Slaughterhouse Wastewater (PSW) Using a Pretreatment Stage, an Expanded Granular Sludge Bed Reactor (EGSB), and a Membrane Bioreactor (MBR). Membranes 2021, 11, 345. [CrossRef]

33. Henze, M.; van Loosdrecht, M.C.; Ekama, G.A.; Brdjanovic, D. Biological Wastewater Treatment; IWA publishing: London, UK, 2008.

34. Njoya, M.; Basitere, M.; Ntwampe, S.K.O. High Rate Anaerobic Treatment of Poultry Slaughterhouse Wastewater (PSW); Nova Science Publishers, Inc.: New York, NY, USA, 2019; Volume 38.

35. Gerardi, M.H. The Microbiology of Anaerobic Digesters; John Wiley \& Sons: Hoboken, NJ, USA, 2003.

36. Dyosile, P.A.; Mdladla, C.; Njoya, M.; Basitere, M.; Ntwampe, S.K.O.; Kaskote, E. Assessment of an Integrated and Sustainable Multistage System for the Treatment of Poultry Slaughterhouse Wastewater. Membranes 2021, 11, 582. [CrossRef] [PubMed]

37. Appels, L.; Baevens, J.; Degrève, J.; Dewil, R. Principios y potencial de la digestión anaerobia de lodos activados por residuos. Prog. Combust. De Energía. Sci. 2008, 34, 755-781. [CrossRef]

38. Del Nery, V.; de Nardi, I.R.; Damianovic, M.H.R.Z.; Pozzi, E.; Amorim, A.K.B.; Zaiat, M. Long-term operating performance of a poultry slaughterhouse wastewater treatment plant. Resour. Conserv. Recycl. 2007, 50, 102-114. [CrossRef]

39. Rajagopal, R.; Saady, N.M.C.; Torrijos, M.; Thanikal, J.V.; Hung, Y.-T. Sustainable Agro-Food Industrial Wastewater Treatment Using High Rate Anaerobic Process. Water 2013, 5, 292-311. [CrossRef]

40. Burton, F.L.; Stensel, H.D.; Tchobanoglous, G.; Metcalf \& Eddy, Inc. Wastewater Engineering: Treatment and Reuse; McGraw Hill: New York, NY, USA, 2003. 
41. Basitere, M.; Williams, Y.; Sheldon, M.S.; Ntwampe, S.K.O.; De Jager, D.; Dlangamandla, C. Performance of an expanded granular sludge bed (EGSB) reactor coupled with anoxic and aerobic bioreactors for treating poultry slaughterhouse wastewater. Water Pr. Technol. 2016, 11, 86-92. [CrossRef]

42. Njoya, M.; Basitere, M.; Ntwampe, S.K.O. Treatment of poultry slaughterhouse wastewater using a down-flow expanded granular bed reactor. Water Pr. Technol. 2019, 14, 549-559. [CrossRef]

43. Cruz-Salomón, A.; Ríos-Valdovinos, E.; Pola-Albores, F.; Lagunas-Rivera, S.; Meza-Gordillo, R.; Ruíz-Valdiviezo, V.M.; CruzSalomón, K.C. Expanded granular sludge bed bioreactor in wastewater treatment. Glob. J. Environ. Sci. Manag. 2019, 5, 119-138. [CrossRef]

44. Kundu, P.; Debsarkar, A.; Mukherjee, S. Kinetic Modeling for Simultaneous Organic Carbon Oxidation, Nitrification, and Denitrification of Abattoir Wastewater in Sequencing Batch Reactor. Bioremediat. J. 2014, 18, 267-286. [CrossRef]

45. Bohdziewicz, J.; Sroka, E. Integrated system of activated sludge-reverse osmosis in the treatment of the wastewater from the meat industry. Process Biochem. 2005, 40, 1517-1523. [CrossRef]

46. Luu, H.M.; Nguyen, N.X.D.; Bui, T.L.M. Treatment of wastewater from slaughterhouse by biodigester and Vetiveria zizanioides L. Livest. Res. Rural Dev. 2014, 26, 68.

47. López-López, A.; Vallejo-Rodríguez, R.; Méndez-Romero, D.C. Evaluation of a combined anaerobic and aerobic system for the treatment of slaughterhouse wastewater. Environ. Technol. 2010, 31, 319-326. [CrossRef]

48. Song, K.; Mohseni, M.; Taghipour, F. Application of ultraviolet light-emitting diodes (UV-LEDs) for water disinfection: A review. Water Res. 2016, 94, 341-349. [CrossRef]

49. Hijnen, W.A.M.; Beerendonk, E.F.; Medema, G.J. Inactivation credit of UV radiation for viruses, bacteria and protozoan (oo)cysts in water: A review. Water Res. 2006, 40, 3-22. [CrossRef]

50. Gibson, J.; Drake, J.; Karney, B. UV Disinfection of Wastewater and Combined Sewer Overflows. Adv. Exp. Med. Biol. 2017, 996, 267-275. [CrossRef] [PubMed]

51. Chevremont, A.C.; Farnet, A.M.; Coulomb, B.; Boudenne, J.L. Effect of coupled UV-A and UV-C LEDs on both microbiological and chemical pollution of urban wastewaters. Sci. Total Environ. 2012, 426, 304-310. [CrossRef]

52. Azaizeh, H.; Linden, K.; Barstow, C.; Kalbouneh, S.; Tellawi, A.; Albalawneh, A.; Gerchman, Y. Constructed wetlands combined with UV disinfection systems for removal of enteric pathogens and wastewater contaminants. Water Sci. Technol. 2013, 67, 651-657. [CrossRef]

53. Vongsayalath, T. Development of Woven Fiber Microfiltration Membrane System for Water and Wastewater Treatment; Asian Institute of Technology: Pathum Thani, Thailand, 2015.

54. Nguyen, T.M.H.; Suwan, P.; Koottatep, T.; Beck, S.E. Application of a novel, continuous-feeding ultraviolet light emitting diode (UV-LED) system to disinfect domestic wastewater for discharge or agricultural reuse. Water Res. 2019, 153, 53-62. [CrossRef] [PubMed]

55. Fatima, F.; Du, H.; Kommalapati, R.R. Treatment of Poultry Slaughterhouse Wastewater with Membrane Technologies: A Review. Water 2021, 13, 1905. [CrossRef]

56. Yan, T.; Ye, Y.; Ma, H.; Zhang, Y.; Guo, W.; Du, B.; Wei, Q.; Wei, D.; Ngo, H.H. A critical review on membrane hybrid system for nutrient recovery from wastewater. Chem. Eng. J. 2018, 348, 143-156. [CrossRef]

57. Jensen, P.D.; Yap, S.D.; Boyle-Gotla, A.; Janoschka, J.; Carney, C.; Pidou, M.; Batstone, D.J. Anaerobic membrane bioreactors enable high rate treatment of slaughterhouse wastewater. Biochem. Eng. J. 2015, 97, 132-141. [CrossRef]

58. Yadav, S.; Ibrar, I.; Bakly, S.; Khanafer, D.; Altaee, A.; Padmanaban, V.C.; Samal, A.K.; Hawari, A.H. Organic Fouling in Forward Osmosis: A Comprehensive Review. Water 2020, 12, 1505. [CrossRef]

59. Skoczko, I.; Puzowski, P.; Szatyłowicz, E. Experience from the Implementation and Operation of the Biological Membrane Reactor (MBR) at the Modernized Wastewater Treatment Plant in Wydminy. Water 2020, 12, 3410. [CrossRef]

60. Svardal, K.; Kroiss, H. Energy requirements for waste water treatment. Water Sci. Technol. 2011, 64, 1355-1361. [CrossRef] [PubMed]

61. Mino, T.; Liu, W.-T.; Kurisu, F.; Matsuo, T. Modelling glycogen storage and denitrification capability of microorganisms in enhanced biological phosphate removal processes. Water Sci. Technol. 1995, 31, 25-34. [CrossRef]

62. Meyer, R.L.; Zeng, R.J.; Giugliano, V.; Blackall, L.L. Challenges for simultaneous nitrification, denitrification, and phosphorus removal in microbial aggregates: Mass transfer limitation and nitrous oxide production. FEMS Microbiol. Ecol. 2005, 52, 329-338. [CrossRef]

63. Mai, Z. Membrane Processes for Water and Wastewater Treatment: Study and Modeling of Interactions between Membrane and Organic Matter. Ph.D. Thesis, Ecole Centrale Paris, Chatenay-Malabry, France, 2013.

64. Le-Clech, P.; Jefferson, B.; Judd, S.J. A comparison of submerged and sidestream tubular membrane bioreactor configurations. Desalination 2005, 173, 113-122. [CrossRef]

65. Ezugbe Obotey, E.; Rathilal, S. Membrane Technologies in Wastewater Treatment: A Review. Membranes 2020, 10, 89. [CrossRef]

66. Bunani, S.; Yörükoğlu, E.; Yüksel, Ü.; Kabay, N.; Yüksel, M.; Sert, G. Application of reverse osmosis for reuse of secondary treated urban wastewater in agricultural irrigation. Desalination 2015, 364, 68-74. [CrossRef]

67. Tchobanoglus, G.; Burton, F.; Stensel, H.D.J.A.W.W.A.J. Wastewater engineering. Treat. Reuse 2003, 95, 201.

68. Ozaki, H.; Sharma, K.; Saktaywin, W.; Wang, D.; Yu, Y. Application of ultra low pressure reverse osmosis (ULPRO) membrane to water and wastewater. Water Sci. Technol. 2000, 42, 123-135. [CrossRef] 
69. Venzke, C.D.; Rodrigues, M.A.S.; Giacobbo, A.; Bacher, L.E.; Lemmertz, I.S.; Viegas, C.; Striving, J.; Pozzebon, S. Application of reverse osmosis to petrochemical industry wastewater treatment aimed at water reuse. Manag. Environ. Qual. Int. J. 2017, 28, 70-77. [CrossRef]

70. Innes, P.; Chang, S.; Rahaman, M.S. Treatment of Effluent of Upflow Anaerobic Sludge Blanket Bioreactor for Water Reuse. Water 2021, 13, 2123. [CrossRef]

71. Yordanov, D. Preliminary study of the efficiency of ultrafiltration treatment of poultry slaughterhouse wastewater. Bulg. J. Agric. Sci. 2010, 16, 700-704.

72. Musa, M.A.; Idrus, S. Physical and Biological Treatment Technologies of Slaughterhouse Wastewater: A Review. Sustainability 2021, 13, 4656. [CrossRef]

73. Valderrama, O.J.; Zedda, K.L.; Velizarov, S. Membrane Filtration Opportunities for the Treatment of Black Liquor in the Paper and Pulp Industry. Water 2021, 13, 2270. [CrossRef]

74. Zhang, S.; Kutowy, O.; Kumar, A.; Malcolm, I. A laboratory study of poultry abattoir wastewater treatment by membrane technology. Can. Agric. Eng. 1997, 39, 99-106.

75. de Morais Coutinho, C.; Chiu, M.C.; Basso, R.C.; Ribeiro, A.P.B.; Gonçalves, L.A.G.; Viotto, L.A. State of art of the application of membrane technology to vegetable oils: A review. Food Res. Int. 2009, 42, 536-550. [CrossRef]

76. Beier, S.P. Pressure Driven Membrane Processes: Downstream Processing, 3rd ed.; Bookboon: London, UK, 2007.

77. Coskun, T.; Debik, E.; Kabuk, H.A.; Manav Demir, N.; Basturk, I.; Yildirim, B.; Temizel, D.; Kucuk, S. Treatment of poultry slaughterhouse wastewater using a membrane process, water reuse, and economic analysis. Desalination Water Treat. 2016, 57, 4944-4951. [CrossRef]

78. Verhuelsdonk, M.; Glas, K.; Parlar, H. Economic evaluation of the reuse of brewery wastewater. J. Environ. Manag. 2021, 281, 111804. [CrossRef] [PubMed]

79. Brennan, B.; Lawler, J.; Regan, F. Recovery of viable ammonia-nitrogen products from agricultural slaughterhouse wastewater by membrane contactors: A review. Environ. Sci. Water Res. Technol. 2021, 7, 259-273. [CrossRef]

80. Ang, W.S.; Lee, S.; Elimelech, M. Chemical and physical aspects of cleaning of organic-fouled reverse osmosis membranes. J. Membr. Sci. 2006, 272, 198-210. [CrossRef]

81. Yu, H.; Huang, W.; Liu, H.; Li, T.; Chi, N.; Chu, H.; Dong, B. Application of Coagulation-Membrane Rotation to Improve Ultrafiltration Performance in Drinking Water Treatment. Membranes 2021, 11, 643. [CrossRef] [PubMed]

82. Li, Z.; Wu, C.; Huang, J.; Zhou, R.; Jin, Y. Membrane Fouling Behavior of Forward Osmosis for Fruit Juice Concentration. Membranes 2021, 11, 611. [CrossRef]

83. Nichka, V.S.; Nikonenko, V.V.; Bazinet, L. Fouling Mitigation by Optimizing Flow Rate and Pulsed Electric Field during Bipolar Membrane Electroacidification of Caseinate Solution. Membranes 2021, 11, 534. [CrossRef] [PubMed]

84. Gkotsis, P.; Banti, D.; Pritsa, A.; Mitrakas, M.; Samaras, P.; Peleka, E.; Zouboulis, A. Effect of Operating Conditions on Membrane Fouling in Pilot-Scale MBRs: Filaments Growth, Diminishing Dissolved Oxygen and Recirculation Rate of the Activated Sludge. Membranes 2021, 11, 490. [CrossRef] [PubMed]

85. Yu, Y.; Lee, S.; Maeng, S.K. Forward osmosis membrane fouling and cleaning for wastewater reuse. J. Water Reuse Desalination 2016, 7, 111-120. [CrossRef]

86. Sardari, K.; Askegaard, J.; Chiao, Y.-H.; Darvishmanesh, S.; Kamaz, M.; Wickramasinghe, S.R. Electrocoagulation followed by ultrafiltration for treating poultry processing wastewater. J. Environ. Chem. Eng. 2018, 6, 4937-4944. [CrossRef]

87. Valladares Linares, R.; Li, Z.; Yangali-Quintanilla, V.; Li, Q.; Amy, G. Cleaning protocol for a FO membrane fouled in wastewater reuse. Desalination Water Treat. 2013, 51, 4821-4824. [CrossRef]

88. Yoon, H.; Baek, Y.; Yu, J.; Yoon, J. Biofouling occurrence process and its control in the forward osmosis. Desalination 2013, 325, 30-36. [CrossRef]

89. Valladares Linares, R.; Yangali-Quintanilla, V.; Li, Z.; Amy, G. NOM and TEP fouling of a forward osmosis (FO) membrane: Foulant identification and cleaning. J. Membr. Sci. 2012, 421-422, 217-224. [CrossRef]

90. Wang, Z.; Tang, J.; Zhu, C.; Dong, Y.; Wang, Q.; Wu, Z. Chemical cleaning protocols for thin film composite (TFC) polyamide forward osmosis membranes used for municipal wastewater treatment. J. Membr. Sci. 2015, 475, 184-192. [CrossRef] 